\title{
MODIFICATION OF CELLULOSE PRODUCTS BY THE USE OF CHITOSAN AND CHITOSAN-ALGINATE NANO-PARTICLES
}

\author{
Kinga Brzoza-Malczewska, Magdalena Kucharska, Marzena Dymel, Beata Pałys, Anna Bacciarelli-Ulacha*
}

Instytut Biopolimerów i Włókien Chemicznych (Institute of Biopolymers and Chemical Fibres), ul. Skłodowskiej-Curie 19/27, 90-570 Łódź, biomater@ibwch.lodz.pl

*Politechnika Łódzka, Wydział Technologii Materiałowych i Wzornictwa Tekstyliów ul. Żeromskiego 116, 90-924 Łódź, Katedra Włókien Sztucznych, anna. bacciarelli@p.lodz.pl

University of Technology,Łódź, Faculty of Material Technologies and Textile Design, Dept. of Man-made Fibers.

\section{Abstract:}

Aim of the presented research was the improvement of fibrous cellulosic products for uses in hygiene and medical sectors. Nano-particles of bioactive polysaccharides were imparted to cellulosic fibrous products to modify their properties: physical-chemical like absorption, biological like antibacterial and antifungal activity, and mechanical. Fibrous materials like dressing gauze, wood-wool, and hygiene tissues were modified by the addition of chitosan and chitosan-alginate nano-particles. Padding and freeze-drying was applied in the coating of the fibrous materials with the nano-sized polymers.

\section{Keywords:}

cellulosic products, nano-particles, chitosan, complex chitosan/alginate $\mathrm{Na} / \mathrm{Ca}$

\section{Introduction}

Since many years, there has been a steadily increasing demand for modern, innovative biomaterials and materials with content of nano-particles bearing special properties are amongst the most advanced products. Traditional materials like gauze, bandages, nonwovens, self-adhesive dressings no more do satisfy the demands; they stick to the wound and cause inconvenience in application. In the case of exudate wounds, the addition of antibiotics is needed. The drawbacks implied modifications introduced to the standard passive dressings to meet the demands. Initially, the prime goal was to protect the wound against microbes from the environment and to maintain a dry wound neighborhood. Dressings from before 1960 practically did not affect the healing of wounds [1]. It was Winter who pioneered the concept of providing and maintaining an optimal wound surrounding during healing [2] that led to the development of dressings from the traditional passive materials to modern functional ones. Advanced dressings not only protect the wound against bacterial infections, but also provide a moist environment that favors the healing process [3]. It was found, in the investigations in wound healing, that epithelialization (growing of fresh skin tissue) accelerates if the wound is covered with a dressing providing adequate moisture.

Available in the market are dressings in which an addition of active substance serves to promote the healing process. Medications slowly released to the wound are mostly chosen as the additive. Offered is a dressing that comprises a mesh, film, and a therapeutic paste [4]. One other example is a dressing compatible with the skin. It does not cause pain when removed nor irritate the skin, and contains a slow-release drug (coculin) [5]. An antibacterial non-irritating, dressing material that promotes blood coagulation was prepared by the addition of a copolymer of vinylsalicylic acid or its methyl ester and methacrylic ester [6]. Known is an occlusive dressing made of alginic acid with content of calcium chloride, disinfectant (chlorohexidine digluconate) and bivalent metal ions. It is antibacterial, does not stick to the wound, and provides comfort in use. A dressing has also been prepared that, when changed, does not tear off epidermis and is particularly suitable in hospital healing of extensive burn and difficult wounds, and transplanted derma. Tetrafluoroethylene and/or its copolymer are being used in the manufacture of the latter dressing [8].

Active hygiene products are not abundantly present in the market; offered is an antibacterial toilet paper with antibacterial agent that becomes active when moist [9], and antiviral 3-layer tissues (Kleenex Co) with addition of an antiviral organic acid and an anti-irritating agent [10]. Other products include antibacterial tissues made by such companies as Cleanic, AA, Tribactic. The moist Cleanic tissues, which contain natural oil from the tea tree, are capable of killing up to $99 \%$ of bacteria. Oceanic AA THERAPY are antibacterial tissues without content of alcohol. Tribactic tissues soaked with an antibacterial agent (isopropanol) are designed for cleaning and disinfection of skin cuts, scratches, and abrasions.

Chitosan, chitin, and their derivatives belong to a family of polymers that exert bio-stimulating activity such as acceleration of wound healing, regeneration and vascularization of tissue, reduction of scars. The anti-microorganisms activity of chitosan includes fungi, anascogenic yeasts and bacteria, the activity being more intense with bacteria $\operatorname{Gram}(+)$ than $\operatorname{Gram}(-)$ [11-13]. Chitosan properties depend upon molecular mass, deacetylation degree, concentration, $\mathrm{pH}$, and composition of the surrounding [14]. It also exhibits good adhesion and coatforming properties, which carries the chance of providing 
an antibacterial coating or playing the role of a carrier for other antimicrobial substances [15]. Such properties along with biocompatibility and biodegradability make chitosan an excellent material for uses in medicine [16-18].

The market of dressing materials has, in the last years, seen a dynamic development. Dressing containing polysaccharides such as chitin, chitosan, and other derivatives are primarily made in Japan and US. One of the materials was prepared by precipitating an active substance on the carrier. Nonwoven Tencel fibers and cotton makes the base that was covered with a solution of chitosan and then the latter was precipitated with sodium hydroxide, washed, and freeze-dried. The resulting product is a porous membrane, which restrains the growth of bacteria and promotes wound healing [19]. A method was prepared for the manufacture of modified nonwovens for medical application by the addition of a chitosan salt to play the role of binding agent thus conferring antimicrobial properties upon the nonwoven along with improved absorption capacity. The material is biocompatible, it does not irritate the skin, nor is it cytotoxic [20,21].

Main goal of the research was to prepare a method for the manufacture of nano-particles of chitosan and the complex chitosan/alginateNa/Ca. Such prepared polymers are characterized by antibacterial and antifungal properties. Dressing materials made with the addition of the prepared polymers are suitable for uses at home and in hospitals

\section{Materials and methods}

\section{Materials}

Virgin chitosan Chito Clear HQG Primex Co, Iceland with quality parameters; average molecular mass $\left({ }^{\prime} M_{v}\right)=372 \mathrm{kD}$, deacetylation degree $(D D)=81 \%$, ash content $=0.22 \%$, content of heavy metals: As $<0.1 ; \mathrm{Cd}<0.1 ; \mathrm{Pb}=0.27 ; \mathrm{Zn}=0.80$; $\mathrm{Hg}<0.05 \%$. Sodium alginate Protanal 10/60FT, FMC Biopolymer Engineering, Inc., USA. Lactic acid pure for analysis (Avantor Co, Gliwice, Poland). Sodium hydroxide pure for analysis (Avantor Co, Gliwice, Poland). Glicerol pure for analysis (Avantor Co, Gliwice, Poland). Calcium lactate (Pharma Cosmetic Co).

Cellulosic textile materials:

- Non-sterile gauze (100\% cotton), surface density $23.5 \mathrm{~g} / \mathrm{m}^{2}$, Merkator Medical Co, Poland (symbol gauze) non-sterile gauze, 8 -layers (100\% cotton), surface density $200 \mathrm{~g} / \mathrm{m}^{2}$, $1.76 \mathrm{~mm}$ thick,

- Tissues Bella No1, twin-layer, $100 \%$ cellulose, surface density $28.1 \mathrm{~g} / \mathrm{m}^{2} ; 0.29 \mathrm{~mm}$ produced by TZMO Co.Toruń, Poland,

- Wood-wool Matocell-in rolls, surface density $89.9 \mathrm{~g} / \mathrm{m}^{2}$; $0.76 \mathrm{~mm}$ thick produced by Matopat TZMO Toruń, Poland.

\section{Methods}

\section{Size estimation of chitosan and complex chitosan/ alginate $\mathrm{Na} / \mathrm{Ca}$}

The size of the nano-particles and distribution of their diameter and volume were estimated by the use of Dynamic Light Scattering (DLS) technique and the apparatus Nicomp 380; Santa Barbara, California, USA and refractometer Abbe 4T [22]

The analysis of particle size was made in an acrylic cuvette sized $1 \mathrm{~cm} \times 1 \mathrm{~cm} \times 4 \mathrm{~cm}$ which, filled with the dispersion, was placed in the thermostatic measuring chamber at $25^{\circ} \mathrm{C}$. The volume and numerical content of the particles were scrutinized. Dynamic viscosity and light refraction index of the analyzed liquid were taken into account to arrive at a correct measurement result.

Prior to the testing, calibration was made of the instrument by measuring the particle size of a standard, equal to $99 \mathrm{~nm}$.

Assessment of antibacterial activity of chitosan nanoparticles, nano-complex chitosan/alg $\mathrm{Na} / \mathrm{Ca}$ and modified cellulosic textile materials

The assessment of antibacterial activity against Escherichia coli and Staphylococcus aureus was made according to standard JIS L 1902:2002, "Examination of antibacterial activity of textile products" Quantitative test.

Assessment of antifungal activity of chitosan nanoparticles, nano-complex chitosan/alg $\mathrm{Na} / \mathrm{Ca}$ and the modified cellulosic textile materials

The assessment of antifungal activity against Candida albicans was made according to standard ASTM: E2149-01 "Standard Test Method for Determining the Antimicrobial Activity of Immobilized Antimicrobial Agent under Dynamic Contact Condition"-Shaking Flask Method.

\section{Estimation of physical-mechanical parameters of the cellulosic textile products.}

The analysis was carried out in the Laboratory of Metrology of IBChF (certificate of accreditation AB 388). Thickness of the gauze, wood-wool, and hygiene tissues was measured according to standard PN-EN ISO 9073-2:2002. Surface density, tenacity elongation, and sinking time was estimated in accordance with standard PN-EN 14079:2004

\section{Results and summary}

Method of preparing nano-particles of chitosan and the complex chit/algNa/Ca.

\section{Nano-chitosan}

One of the research objectives was to elaborate a method for the preparation of nano-particle of chitosan and complex chitosan/ 
alginate/ $\mathrm{Na} / \mathrm{Ca}$ with dimensions below $1 \mu \mathrm{m}$. The ultrasonic reactor Hielscher UP 200S equipped with sonotrode S14L2D served to prepare the nano-particles. A $0.1 \mathrm{wt} \%$ aqueous sodium hydroxide and a $0.2 \mathrm{wt} \%$ chitosan lactate solution were used to prepare microcrystalline chitosan $(\mathrm{MCCH})$. A peristaltic pump was continuously feeding aqueous sodium hydroxide to the solution of chitosan lactate, which was subjected to ultrasounds at $52.5\left(\mathrm{~W} / \mathrm{cm}^{2}\right)$ of acoustic density and at a maximal immersion of the sonotrode- $40 \mathrm{~mm}$. The coagulation of chitosan lactate was continued at $20,30^{\circ} \mathrm{C}$ directly in the stream of the ultrasounds until $\mathrm{pH}$ of the suspension reached the level of $6.7-6.8$. Coagulation completed, the prepared suspension of the polymer was for 20 minutes put to a further action of ultrasounds at acoustic density of $30,52.5\left(\mathrm{~W} / \mathrm{cm}^{2}\right)$. A suspension of chitosan nano-particles with concentration of $0.14 \%$ was obtained.

\section{Complex chitosan/alg $\mathrm{Na} / \mathrm{Ca}$ (complex chit/alg/Na/Ca)}

$0.13 \mathrm{wt} \%$ aqueous solution of chitosan lactate with addition of calcium ions in the amount of $0.0052 \mathrm{~g}$ on $100 \mathrm{~g}$ of the chitosan solution, and a $0.045 \mathrm{wt} \%$ alkaline solution of sodium alginate were used to prepare the suspension of the complex chit/alg/ $\mathrm{Na} / \mathrm{Ca}$. The coagulation process of the solution of chitosan lactate with addition of calcium ions by the alkaline solution of sodium alginate was conducted the same way as in the process of preparing chitosan nano-particles. Result of the reaction was the complex chit/alg/Na/Ca with chitosan content in the complex of $90 \%$.

Estimation of the nano- particle size in chitosan and complex chit/algNa/Ca.

The particle size distribution in the prepared biopolymers was analyzed by DLS method. Obtained results are presented in Table 1

The applied method with the use of the ultrasonic homogenizer presents the chance of preparing chitosan- and complex chit/ algNa/Ca having particles sized below 1 micron. About $70 \%$ of chitosan and complex chit/alg/ $\mathrm{Na} / \mathrm{Ca}$ particles were about $585 \mathrm{~nm}$ and $500 \mathrm{~nm}$, respectively, in size

Assessment of antibacterial activity of chitosan- and complex chit/algNa/Ca nano-particles, and modified cellulosic materials.

It was assumed that the prepared polymer nano-particles would be used in the modification of cellulosic textile materials such as: hygiene tissues, wood-wool, dressing gauze by imparting antimicrobial properties. The cellulosic materials were surfacemodified with the nano-particles of chitosan and complex chit/ $\mathrm{alg} / \mathrm{Na} / \mathrm{Ca}$. An aqueous suspension of the nano-particles with polymer concentration of about $0.5-0.8 \mathrm{wt} \%$ was used in the coating process. The modified textile products were for 20 to 24 hours freeze-dried by the use of the lyophilizer ALFA 2-4 LD Plus from Martin Christ $\mathrm{GmbH}$ in the temperature range from $(-20)$ to $10^{\circ} \mathrm{C}$ at vacuum of from 0.1 to $0.7 \mathrm{mbar}$.

The prepared polymers with nano-metric dimensions and the modified cellulosic materials were tested with regard to antimicrobial activity against bacteria $E$. coli and $S$. aureus. The testing was made after sterilization of the samples with fast electrons at dose of $25 \mathrm{kGy}$. Results of the antibacterial examination are compiled in Tables 2-3

The results of antibacterial examination testify that both polymers with nano-particles exhibit bacteriostatic activity against $E$. coli on the level of 6.6-6.9 and are bactericidal on the level of 2.7-3.0. Both activities are slightly lower against S. aureus: Bacteriostatic is in the limits of 5.1-5.6 and bactericidal of 3.2-3.8 (Tables 2-3).

An ability to reduce bacteria $E$. coli and $S$. aureus on the level of 3.9-6.8 (Table 2) was observed in cellulosic textile materials modified with chitosan nano-particles, while modification with the complex chit/alg/ $\mathrm{Na} / \mathrm{Ca}$ produced a reduction of $2.8-5.4$ (Table 3).

\section{Assessment of antifungal activity of chitosan-and complex chit/algNa/Ca nano-particles, and modified cellulosic materials.}

The cellulosic textile materials surface-modified with chitosanand chit/alg/Na/Ca nano-particles were tested with regard to antifungal activity against fungi $C$. albicans. The samples were sterilized with fast electrons at dose of $25 \mathrm{kGy}$. Results of the antibacterial examination are compiled in Table 4

Both polymers with nano-sized particles as well as the modified cellulosic textile materials revealed an excellent antifungal activity. The reduction of the fungi $C$. albicans was $100 \%$ or close to $100 \%$ in all tested materials (Table 4).

\section{Assessment of physical-mechanical parameters of the cellulosic textile materials.}

Physical-mechanical parameters of the cellulosic textile materials were estimated before and after the modification with the polymers in nano-dimensions. Assessed were following

Table 1. Size of nano-particles analyzed by DLS method, NICOMP distribution

\begin{tabular}{|c|c|c|c|c|c|c|c|}
\hline \multirow{2}{*}{$\begin{array}{l}\text { Analyzed } \\
\text { sample }\end{array}$} & \multirow{2}{*}{$\begin{array}{l}\text { No. of } \\
\text { fraction }\end{array}$} & \multicolumn{2}{|c|}{ Volume weighting } & \multicolumn{2}{|c|}{ Numerical weighting } & \multicolumn{2}{|c|}{ Intensity weighting } \\
\hline & & Diameter, nm & Percentage & Diameter, nm & Percentage & Diameter , nm & Percentage \\
\hline \multirow{2}{*}{$\begin{array}{c}\text { nano- } \\
\text { chitosan }\end{array}$} & 1 & 59.5 & 31.7 & 54.3 & 99.7 & 541.6 & 100 \\
\hline & 2 & 584.7 & 68.3 & 506.7 & 0.3 & - & - \\
\hline \multirow{2}{*}{$\begin{array}{c}\text { nano- } \\
\text { complex } \\
\text { chit/alg } \\
\mathrm{Na} / \mathrm{Ca}\end{array}$} & 1 & 47.4 & 29.7 & 47.1 & 82.4 & 48.4 & 1.1 \\
\hline & 2 & 500.8 & 70.3 & 493.6 & 17.6 & 493.6 & 98.9 \\
\hline
\end{tabular}


Table 2. Assessment of antibacterial activity of the cellulosic textile materials modified with chitosan nano-particles.

\begin{tabular}{|c|c|c|c|c|c|c|}
\hline \multirow[t]{2}{*}{ Analyzed sample } & \multirow[t]{2}{*}{ Time $[\mathrm{h}]$} & \multirow{2}{*}{$\begin{array}{c}\text { No. of } \\
\text { bacteria } \\
\text { [cfu/ } \\
\text { sample] }\end{array}$} & \multicolumn{2}{|c|}{$\begin{array}{c}\text { Bacteriostatic } \\
\text { activity against } \\
E . \text { coli }\end{array}$} & \multicolumn{2}{|c|}{$\begin{array}{c}\text { Bactericidal } \\
\text { activity against } \\
\text { E. coli }\end{array}$} \\
\hline & & & Log & $\%$ & Log & $\%$ \\
\hline nano-chitosan & 24 & $<20$ & 6.9 & 100 & 2.7 & 100 \\
\hline Gauze/nano-chit & 24 & $1.9 \times 10^{4}$ & 3.9 & 56.3 & 0.2 & 6.3 \\
\hline $\begin{array}{c}\text { Wood-wool/ } \\
\text { nano-chitosan }\end{array}$ & 24 & $1.0 \times 10^{3}$ & 5.1 & 75.0 & 1.6 & 48.5 \\
\hline $\begin{array}{c}\text { Tissues/ } \\
\text { nano-chitosan }\end{array}$ & 24 & $<20$ & 6.8 & 100 & 3.3 & 100 \\
\hline \multirow[t]{2}{*}{ Analyzed sample } & \multirow[t]{2}{*}{ Time $[\mathrm{h}]$} & \multirow{2}{*}{$\begin{array}{c}\text { No. of } \\
\text { bacteria [cfu/ } \\
\text { sample] }\end{array}$} & \multicolumn{2}{|c|}{$\begin{array}{l}\text { Bacteriostatic } \\
\text { activity against } \\
\text { S. aureus }\end{array}$} & \multicolumn{2}{|c|}{$\begin{array}{l}\text { Bactericidal } \\
\text { activity against } \\
\text { S. aureus }\end{array}$} \\
\hline & & & Log & $\%$ & Log & $\%$ \\
\hline nano-chitosan & 24 & $<20$ & 5.1 & 100 & 3.2 & 100 \\
\hline $\begin{array}{c}\text { Gauze/ } \\
\text { nano-chitosan }\end{array}$ & 24 & $6.0 \times 10^{1}$ & 5.1 & 91.1 & 2.8 & 84.8 \\
\hline $\begin{array}{c}\text { Wood-wool/ } \\
\text { nano-chitosan }\end{array}$ & 24 & $2.3 \times 10^{1}$ & 5.3 & 98.1 & 3.2 & 98.1 \\
\hline $\begin{array}{c}\text { Tissues/ } \\
\text { nano-chitosan }\end{array}$ & 24 & $2.24 \times 10^{1}$ & 5.3 & 98.1 & 3.2 & 98.1 \\
\hline
\end{tabular}

Table 3. Assessment of antibacterial activity of the cellulosic textile materials modified with complex chit/alg Na/Ca nano-particles.

\begin{tabular}{|c|c|c|c|c|c|c|}
\hline \multirow[t]{2}{*}{ Analyzed sample } & \multirow[t]{2}{*}{ Time $[\mathrm{h}]$} & \multirow{2}{*}{$\begin{array}{c}\text { No. of } \\
\text { bacteria } \\
\text { [cfu/sample] }\end{array}$} & \multicolumn{2}{|c|}{$\begin{array}{c}\text { Bacteriostatic } \\
\text { activity against } \\
\text { E. coli }\end{array}$} & \multicolumn{2}{|c|}{$\begin{array}{c}\text { Bactericidal } \\
\text { activity against } \\
\text { E. coli }\end{array}$} \\
\hline & & & $\log$ & $\%$ & $\log$ & $\%$ \\
\hline $\begin{array}{l}\text { nano-complex } \\
\text { chit/algNa/Ca }\end{array}$ & 24 & $<20$ & 6.6 & 100 & 3.0 & 100 \\
\hline $\begin{array}{c}\text { Gauze/nano-complex chit/ } \\
\text { algNa/Ca }\end{array}$ & 24 & $8.9 \times 10^{4}$ & 3.2 & 47.1 & -0.1 & 0.0 \\
\hline $\begin{array}{c}\text { Wood-wool/nano-complex } \\
\text { chit/algNa/Ca }\end{array}$ & 24 & $2.9 \times 10^{4}$ & 2.8 & 46.7 & 0.0 & 0.0 \\
\hline $\begin{array}{c}\text { Tissues/nano-complex chit/ } \\
\text { algNa/Ca }\end{array}$ & 24 & $2.3 \times 10^{3}$ & 3.9 & 65.0 & 1.1 & 34.4 \\
\hline \multirow[t]{2}{*}{ Analyzed sample } & \multirow[t]{2}{*}{ Times $[\mathrm{h}]$} & \multirow[t]{2}{*}{$\begin{array}{c}\text { No. of } \\
\text { bacteria [cfu/ } \\
\text { sample] }\end{array}$} & \multicolumn{2}{|c|}{$\begin{array}{l}\text { Bacteriostatic } \\
\text { activity } \\
\text { against } \\
\text { S. aureus }\end{array}$} & \multicolumn{2}{|c|}{$\begin{array}{l}\text { Bactericidal } \\
\text { activity } \\
\text { against } \\
\text { S. aureus }\end{array}$} \\
\hline & & & $\log$ & $\%$ & $\log$ & $\%$ \\
\hline $\begin{array}{l}\text { nano-complex } \\
\text { chit/algNa/Ca }\end{array}$ & 24 & $<20$ & 5.6 & 100 & 3.5 & 100 \\
\hline $\begin{array}{c}\text { Gauze/nano-complex } \\
\text { nano-complex } \\
\text { chit/algNa/Ca }\end{array}$ & 24 & $5.7 \times 10^{2}$ & 4.0 & 72.7 & 2.0 & 57.1 \\
\hline $\begin{array}{c}\text { Wood-wool/nano-complex } \\
\text { chit/algNa/Ca }\end{array}$ & 24 & $8.8 \times 10^{2}$ & 4.0 & 71.4 & 1.8 & 52.9 \\
\hline $\begin{array}{c}\text { Tissues/nano-complex chit/ } \\
\text { algNa/Ca }\end{array}$ & 24 & $3.0 \times 10^{1}$ & 5.4 & 96.4 & 3.2 & 94.1 \\
\hline
\end{tabular}


Table 4. Antifungal activity against Candida albicans of cellulosic textile materials modified with nano-particles of chitosan.

\begin{tabular}{|c|c|c|c|c|c|c|}
\hline \multirow[b]{2}{*}{ Analyzed sample } & \multicolumn{6}{|c|}{ Test after $24 \mathrm{~h}$ incubation } \\
\hline & Repet. & cfu/ml & $\begin{array}{c}\text { Reduction } \\
\text { C. albicans, \% }\end{array}$ & $\begin{array}{c}\text { Average } \\
\text { reduction, } \\
\%\end{array}$ & $\begin{array}{l}\text { Reduction } \\
\text { C. albicans, log }\end{array}$ & $\begin{array}{c}\text { Average } \\
\text { reduction, log }\end{array}$ \\
\hline \multirow{2}{*}{ nano-chitosan } & 1 & $3.2 \times 10^{1}$ & 99.97 & \multirow{2}{*}{99.98} & 3.57 & \multirow{2}{*}{3.62} \\
\hline & II & $2.6 \times 10^{1}$ & 99.98 & & 3.67 & \\
\hline \multirow{2}{*}{ Gauze/nano-chit } & 1 & $<1$ & 100 & \multirow{2}{*}{100.0} & 5.1 & \multirow{2}{*}{5.1} \\
\hline & II & $<1$ & 100 & & 5.1 & \\
\hline \multirow{2}{*}{ Wood-wool/nano-chit } & 1 & $4.0 \times 10^{0}$ & 99.99 & \multirow{2}{*}{99.99} & 4.6 & \multirow{2}{*}{4.7} \\
\hline & II & $3.0 \times 10^{0}$ & 99.99 & & 4.7 & \\
\hline \multirow{2}{*}{ Tissues/nano-chit } & I & $1.3 \times 10^{2}$ & 99.99 & \multirow{2}{*}{99.99} & 4.1 & \multirow{2}{*}{4.0} \\
\hline & II & $2.2 \times 10^{2}$ & 99.98 & & 3.9 & \\
\hline \multirow{2}{*}{$\begin{array}{c}\text { nano-complex chit/algNa/ } \\
\mathrm{Ca}\end{array}$} & 1 & $1.1 \times 10^{1}$ & 99.99 & \multirow{2}{*}{99.66} & 4.04 & \multirow{2}{*}{3.11} \\
\hline & II & $8.1 \times 10^{1}$ & 99.32 & & 3.17 & \\
\hline \multirow{2}{*}{$\begin{array}{c}\text { Gauze/nano-complex chit/ } \\
\text { algNa/Ca }\end{array}$} & 1 & $8.5 \times 10^{1}$ & 99.80 & \multirow{2}{*}{99.90} & 2.8 & \multirow{2}{*}{3.3} \\
\hline & II & $1.4 \times 10^{1}$ & 100 & & 3.7 & \\
\hline \multirow{2}{*}{$\begin{array}{c}\text { Wood-wool/nano-complex } \\
\text { chit/algNa/Ca }\end{array}$} & I & $4.0 \times 10^{0}$ & 100 & \multirow{2}{*}{100} & 4.6 & \multirow{2}{*}{4.4} \\
\hline & II & $8.5 \times 10^{0}$ & 99.99 & & 4.2 & \\
\hline \multirow{2}{*}{$\begin{array}{l}\text { Tissues nano-complex chit/ } \\
\text { algNa/Ca }\end{array}$} & I & $1.5 \times 10^{2}$ & 99.90 & \multirow{2}{*}{99.90} & 3.0 & \multirow{2}{*}{3.0} \\
\hline & II & $1.6 \times 10^{2}$ & 99.90 & & 3.0 & \\
\hline
\end{tabular}

Table 5 . Metrological parameters of the cellulosic materials before and after modification.

\begin{tabular}{|c|c|c|c|c|c|c|}
\hline Analyzed sample & $\begin{array}{c}\text { Surface mass } \\
{\left[\mathbf{g} / \mathbf{m}^{2}\right]}\end{array}$ & $\begin{array}{c}\text { Breaking } \\
\mathbf{f o r c e} \\
{[\mathbf{N}]}\end{array}$ & $\begin{array}{c}\text { Elongation } \\
\text { at break } \\
{[\%]}\end{array}$ & $\begin{array}{c}\text { Tenacity } \\
{[\mathrm{MPa}]}\end{array}$ & $\begin{array}{c}\text { Thickness } \\
{[\mathrm{mm}]}\end{array}$ & $\begin{array}{c}\text { Sinking time } \\
{[\mathbf{s}]}\end{array}$ \\
\hline Gauze & $201 \pm 4$ & $868 \pm 48$ & $11 \pm 1$ & $9.87 \pm 0.55$ & $1.76 \pm 0.05$ & 1 \\
\hline Gauze/nano-chitosan & $240 \pm 2$ & $1006 \pm 28$ & $11 \pm 1$ & $6.62 \pm 0.18$ & $3.04 \pm 0.05$ & 3 \\
\hline $\begin{array}{c}\text { Gauza/nano-complex chit/ } \\
\text { algNa/Ca }\end{array}$ & $251 \pm 2$ & $876 \pm 41$ & $11 \pm 1$ & $6.77 \pm 0.32$ & $2.59 \pm 0.06$ & 3 \\
\hline Wood-wool & $89.9 \pm 2.0$ & $3.9 \pm 0.5$ & $7.8 \pm 2.6$ & $0.10 \pm 0.02$ & $0.76 \pm 0.04$ & 2 \\
\hline Wood-wool/nano-chitosan & $122 \pm 5$ & $23.9 \pm 3.3$ & $16.1 \pm 4.3$ & $0.30 \pm 0.04$ & $1.60 \pm 0.08$ & 5 \\
\hline $\begin{array}{c}\text { Wood-wool/nano-complex } \\
\text { chit/algNa/Ca }\end{array}$ & $109 \pm 2$ & $19.6 \pm 2.7$ & $18.9 \pm 3.7$ & $0.34 \pm 0.04$ & $1.15 \pm 0.08$ & 1 \\
\hline $\begin{array}{c}\text { Tissues } \\
\text { Wissues/nano-chitosan }\end{array}$ & $28.1 \pm 0.2$ & $15.5 \pm 0.7$ & $11.0 \pm 0.5$ & $1.07 \pm 0.05$ & $0.29 \pm 0.02$ & 1 \\
\hline $\begin{array}{c}\text { Tissues/nano-complex } \\
\text { chit/algNa/Ca }\end{array}$ & $37.9 \pm 1.0$ & $28.8 \pm 1.6$ & $14.7 \pm 1.1$ & $1.92 \pm 0.11$ & $0.30 \pm 0.02$ & 5 \\
\hline
\end{tabular}


features: surface mass, elongation at break, tenacity, thickness, and absorption expressed as sinking time or entire imbibition

The modification of the cellulosic materials with nano-particles of chitosan and complex chit/algNa/Ca resulted in an increase of thickness, surface density, and breaking force.

Tenacity increased in wood-wool and tissues, while braking force was up in the gauze along with a reduction of tenacity as a result of much increased thickness. A slight increase in the sinking time was seen, yet it still falls into the limits demanded by standard PN-EN 14079:2004 (Inactive medical materials -Functional demands and methods of testing hygroscopic gauze from cotton and blends of cotton with viscose)

\section{Conclusions}

The proposed ultrasound processing of chitosan and complex chit/algNa/Ca leads to reduction of the polymers' particle size to nano range.

The size of the chitosan particles of chitosan falls into the range of $59.5-584.7 \mathrm{~nm}$, with the major part of about $70 \%$ being $584.7 \mathrm{~nm}$.

The size of the chit/algNa/Ca particles falls into the range $47.4-500.8 \mathrm{~nm}$, with a majority of about $70 \%$ being $500.8 \mathrm{~nm}$.

Both nano-sized biopolymers exhibit a very high bacteriostatic and bactericidal activity against bacteria $E$. coli and S. aureus.

Materials with very high bacteriostatic activity against gram (-) E. coli and gram (+) S. aureus were prepared by modifying cellulosic materials like gauze, wood-wool and tissues with freeze-dried chitosan and complex chit/algNa/Ca

The modified cellulosic textile materials revealed high antifungal activity against $C$. albicans. The strain was reduced by nearly $100 \%$.

Tenacity of wood-wool and tissues increased after modification with the biopolymers.

\section{Acknowledgement}

The part of investigations presented was carried out within the research project

No NCBiR/ERA-NET-MATERA/01/2011 supported by the Ministry of Science and Higher Education

\section{References}

[1] I. V. Yannas and J. F. Burke, Journal of Biomedical Materials Research, 14(1), 65 (1980)
[2] Winter G.D., 1962, Nature, 193, 293-294

[3] J. F. Prudden, P. Migel, P. Hanson, L. Friedrich, and L.Balassa, Am. J. Surg. , 119(5), 560 (1970)

[4] JP2005211647 MURATA TAKAAKI "FIRST AID ADHESIVE PLASTER WITH PASTE"

[5] CN1557310 PAN WEISAN, WANG LEI „Sinlmenine hydrochloride plaster and its preparation method"

[6] JP63270060 „ANTIBACTERIAL ADHESIVE MEMBER”

[7] WO 2006112533 A1, Tetsuya Ishii, Manabu Kanayama, "Water-containing gel form and production method thereof"

[8] US3930498 Andre Monnet, Maurice Cessiecq „Antiadherent medical dressings and the like"

[9] Richard, Beverly, US 20030143372 A1 „Antibacterial toilet tissue"

[10] Gary L. Shanklin, US 7115273, „Anti-viral Lotion Tissue, And Methods For Making And Using The Same"

[11] Rhoades J., Roller S.: Appl. Environ. Microbiol., 66, 80,2000 .

[12] No H. K., Park N. Y., Lee S. H., Meyers S. P.: Int. J. Food Microbiol. 2002, 74, 65.

[13] Jeon Y. J., Park P.-J., Kim S.-K.: Carbohydr. Polym., 44, 71, 2001

[14] Gottfrield K., Sztuka K., Statroszczyk H., Kołodziejska I.,: Biodegradowalne $i$ jadalne opakowania do żywności $z$ polimerów naturalnych.( Biodegradable, edible packaging materials of natural polymers for food. Opakowanie (Packaging Materials), 8, 26-36 2010

[15] B. Smitha, S. Sridhar, A.A.Khan, "Chitosan-sodium alginate polyion complexes as fuel cell membranes", European Polymer Journal 2005, 41, 1859.

[16] Yamamura K., Kuranuk N., Suzuki M., Tanigami T., Matsuzawa S. J.: J. Appl. Polym. Sci., 41, 1990, 2409 2425.

[17] Muzzarelli R. A. A.: Carbohydrate Polym. 20, 1993, 7 - 10.

[18] Struszczyk H.: „Medical application of chitosan” Monography, Tampere, Finland, 1991 - 1992

[19] Lou, Ching-Wen "Process technology and properties evaluation of a chitosan-coated Tencel/cotton nonwoven fabric as a wound dressing" Fibers and Polymers Volume: 9, Issue: 3, June 2008, pp. 286- 292

[20] Struszczyk MH, Ratajska M, Brzoza- Malczewska K. Fibres \& Textiles in Eastern Europe 2007; 15, 2(61): 105109.

[21] Struszczyk MH, Brzoza-Malczewska K, Szalczynska M. Fibres \& Textiles in Eastern Europe 2007; 15, 5-6(64-65): 163-166.

[22] B. Maxit,Particle size measurements of dark and concentrated dispersions by dynamic light scattering Cordouan Technologies, 33400 Pessac, France. 